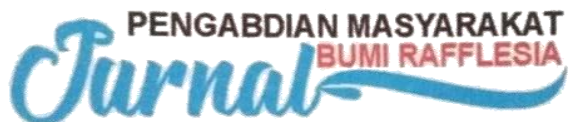

\section{PELATIHAN KETERAMPILAN DASAR KOMPUTER DAN TEKNOLOGI INFORMASI BAGI PERANGKAT DESA PURBOSARI KECAMATAN SELUMA BARAT KABUPATEN SELUMA}

\author{
Muntahanah*' Khairunnisyah, Rozali Toyib, Yulia Darnita \\ Program Studi Informatika, Fakultas Teknik, Universitas Muhammadiyah Bengkulu \\ *Corresponding author: muntahanah@umb.ac.id
}

\begin{abstract}
ABSTRAK
Desa Purbosari merupakan daerah administratif Kecamatan Seluma Barat Kabupaten Seluma, Desa Purbosari Terletak dikabupaten Seluma sejarah terbentuknya Desa Purbosari di mulai dari tahun 1990 adalah awal pemukiman transmigrasi warga eks Kedung ombo , yang bernama UPT Seluma Kanan. Kemudian pada tahun 1994 UPT Seluma Kanan berubah menjadi Desa Definitif dengan nama PURBOSARI yang berarti gabungan dari nama kabupaten Purwodadi , Boyolali dan Sragen. Keadaan Ekonomi Masyarakat Desa Purbosari Hanya 2 Kategori. $50 \%$ Menengah keatas dan $50 \%$ Menengah ke bawah. Hambatan yang dialami oleh aparat desa untuk pencairan dana bantuan atau pengalokasian terkendala dengan data yang ada dikarena masih sederhana dan pendataannya masih secara sederhana sehingga membutukan waktu yang lama untuk menyusun proposal yang diajukan dan kadang karena keterbatasan kemampuan aparat desa yang berhubungan dengan teknologi khususnya komputer menghambat mereka dalam bekerja dan minimnya kemampuan menyusun proposal dan data keuangan sehingga bantuan yang diberikan dapat segera cairkan oleh pemerintah. Manfaat yang dapat diperoleh adalah dengan pelatihan ini diharapkan perangkat desa bisa membuat proposal, surat menyurat, pembukuan sederhana, administrasi dan bisa mencari informasi secara langsung dengan menggunakan teknologi yang dipelajar khususnya internet.
\end{abstract}

Kata Kunci: Aparat, Data, Keuangan, Pembukuan, Proposal

\section{PENDAHULUAN}

Perpres 131/2015 merupakan pintu gerbang dalam melakukan pembangunan daerah tertinggal terlebih percepatan pembangunan daerah tertinggal merupakan implmentasi dari agenda Nawa Cita ketiga yaitu membangun Indonesia dari pinggiran dengan memperkuat daerah-daerah dan desa dalam kerangka negara kesatuan . dalam RPJM 2015-2019, sasaran yang hendak dicapai dalam pembangunan daerah tertinggal pada tahun 2019 ialah peningkatan rata-rata pertumbuhan ekonomi di daerah tertinggal sebesar 7,24 persen, penurunan rata-rata presentase penduduk miskin di daerahtertinggal menjadi 14.00 persen, peningkatan indeks pembangunan manusia (IPM) di daerah tertinggal sebesar 69,59 persen, dan minimal terdapat 80 kabupaten yang di entaskan menjadi kabupatenmaju, berdasarkan Perpres 131/2015 tersebut kabuapten Seluma merupakan satu-satunya 
kabupaten di provinsi Bengkulu yang masih dikatagorikan tertinggal.

Kabupaten Seluma merupakan Kabupaten dalam Provinsi Bengkulu yang merupakan hasil pemekaran dari Kabupaten Bengkulu Selatan. Bila ditinjau dari letak garis bujur dan lintangnya berada pada koordinat $03^{\circ} 49^{\prime} 55^{\prime} 66^{\prime \prime} \mathrm{LS}-04^{\circ} 21^{\prime} 40^{\prime} 22^{\prime \prime}$ LS dan $101^{\circ} 17^{\prime} 27^{\prime}$ 57' BT $102^{\circ} 59^{\prime} 40^{\prime} 54^{\prime \prime}$ BT dan secara geografis wilayah Kabupaten Seluma berada di Pantai Barat Pulau Sumatera bagian Selatan.

Selama 14 tahun sejak terbentuk sebagai kabupaten, kabupaten seluma terus giat melakukan pembangunan di berbagai sektor. Namun upaya pembangunan terhambat dalam berbagai sektor sehingga menempatkan Kabupaten Seluma sebagai salah satu kabupaten tertinggal di provinsi Bengkulu. Beberapa faktor yang menyebabkan ketertinggalan di Kabupaten Seluma adalah sebagai berikut :

1. Tingginya angka kemiskinan

2. Rendahnya pendapatan/pengeluaran per kapita penduduk

3. Rendahnya harapan hidup

4. Rendahnya kemampuan keuagan daerah.

5. Minimnya sarana dan prasarana infrastruktur dasar, fasilitas pendidikan, dan kesehatan

6. Karakteristik daerah yang termasuk pada daerah rawan bencana.

Desa Purbosari merupakan daerah administratif Kecamatan Seluma Barat Kabupaten Seluma, Desa Purbosari Terletak dikabupaten Seluma sejarah terbentuknya Desa Purbosari di mulai dari tahun 1990 adalah awal pemukiman transmigrasi warga eks Kedung ombo, yang bernama UPT Seluma Kanan. Kemudian pada tahun 1994 UPT Seluma Kanan berubah menjadi Desa Definitif dengan nama PURBOSARI yang berarti gabungan dari nama kabupaten Purwodadi , Boyolali dan Sragen.

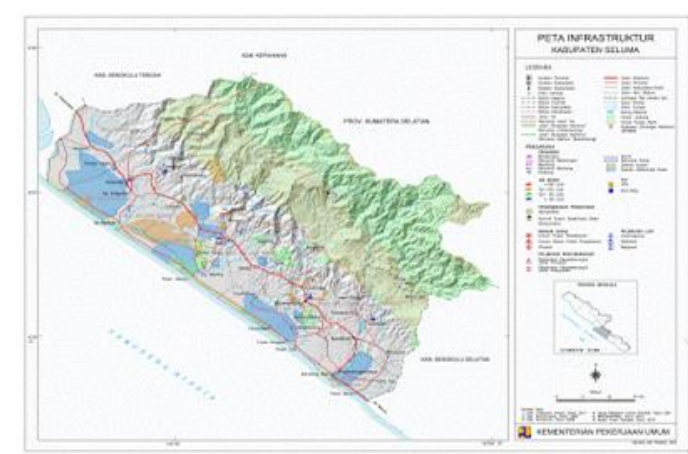

Gambar 1.1 Peta Kabupaten seluma

Keadaan Ekonomi Masyarakat Desa Purbosari Hanya 2 Kategori. $50 \%$ Menengah keatas dan $50 \%$ Menengah ke bawah. Untuk mengecek ekonomi masyrakat desa maka di adakan pendataan ekonomi untuk menentukan warga ekonomi kebawah di hitung dari pendapataan perbulan serta mengecek Aset kepemilikan lainnya. Jarak desa Purbosari dengan jalan lintas provinsi $\pm 7 \mathrm{~km}$, Akses jalan menuju desa berupa jalan koral dan sebagian jalan telah diaspal, Jarak desa ke kota provinsi adalah $60 \mathrm{~km}$ dengan waktu tempuh 90 menit dan Transportasi dari desa dan ke desa purbosari sudah cukup baik dan memadai. Namun untuk kendaraan harus baik kondisinya dikarenakan jalan yang menghubungkan desa masuk kategori rusak sedang.

Pembagian wilayah pemerintahan PURBOSARI di bagi menjadi 5 dusun, dan masing-masing dusun tidak sama pembagian wilayahnya :

1. Dusun II melingkupi wilayah rt 5, rt 15 dan rt 16

2. Dusun III melingkupi wilayah $\mathrm{rt} 11, \mathrm{rt}$ 12, rt 13 dan rt 14

3. Dusun IV melingkupi wilayah rt 6, rt 7 dan rt 10

4. Dusun V melingkupi wilayah rt 8, rt 9 dan rt 17.

5. Tabel 1.1 Jumlah Penduduk Berdasarkan Umur

\begin{tabular}{|c|c|c|c|}
\hline No & $\begin{array}{c}\text { Tingkat } \\
\text { Umur (th) }\end{array}$ & Jumlah Orang & Persentase (\%) \\
\hline 1 & $0-5$ & 119 & 6,4 \\
\hline 2 & $6-12$ & 190 & 10,22 \\
\hline
\end{tabular}




\begin{tabular}{|c|c|c|c|}
3 & $13-17$ & 225 & 12,1 \\
\hline 4 & $18-24$ & 330 & 17,75 \\
\hline 5 & $25-30$ & 250 & 13,44 \\
\hline 6 & $31-35$ & 165 & 8,87 \\
\hline 7 & $36-45$ & 215 & 11,56 \\
\hline 8 & $46-50$ & 125 & 6,72 \\
\hline 9 & $51-60$ & 140 & 7,53 \\
\hline 10 & $>60$ & 100 & 5,37 \\
\hline \multicolumn{2}{|c|}{ JUMLAH } & 1859 org & $99,96 \%$ \\
\hline
\end{tabular}

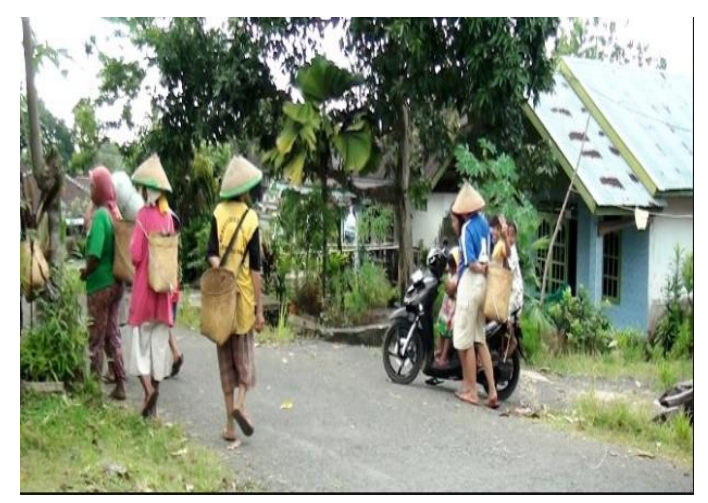

Gambar 1.2. Suasana Desa Purbosari

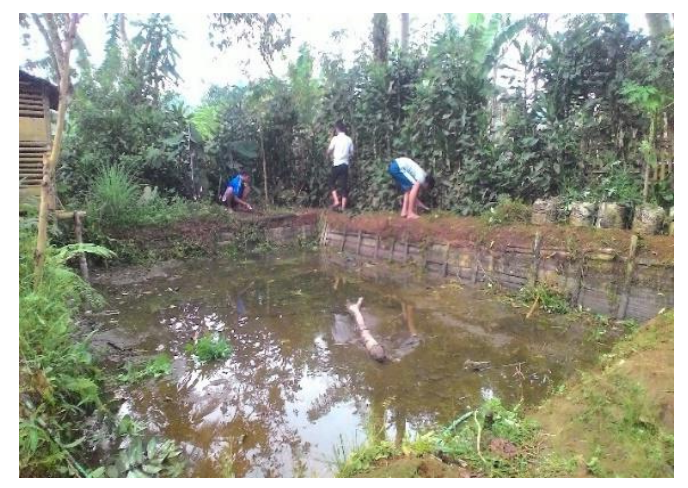

Gambar 1.3. Potensi Wilayah

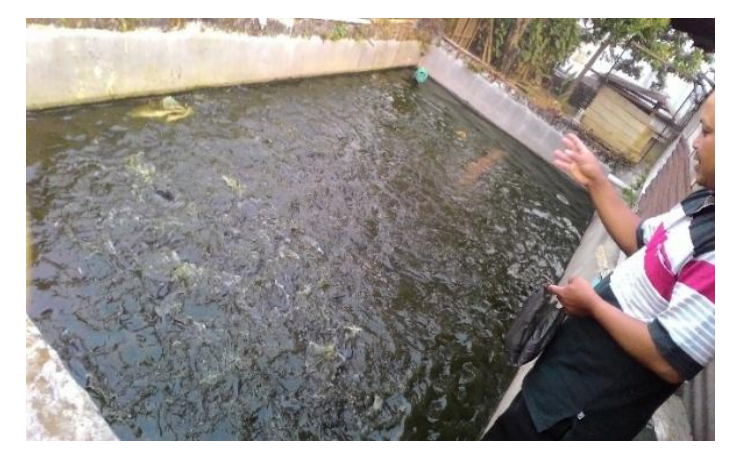

Gambar 1.4. Kolom Ikan

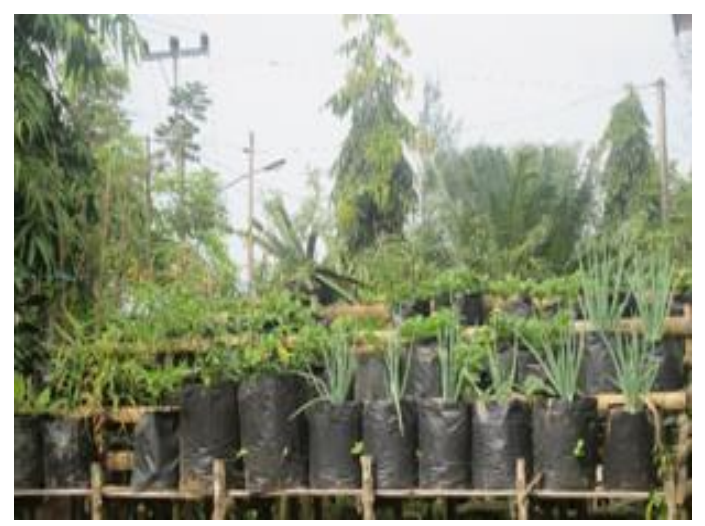

Gambar 1.5. Kreatifitas Masyarakat

Perkembangan teknologi informasi dan komunikasi (TIK) secara masif mempengaruhi semua sektor kehidupan, semua tingkatan saat ini dan masa depan mulai berorientasi kepada perkembangan dan perubahan global, ilmu pengetahuan, teknologi seni dan budaya. Penguasaan teknologi informasi dan komunikasi menjadi penting karena setiap pihak yang terlibat di dalamnya dituntut mampu berpartisipasi secara aktif dan terus meningkatkan kemampuan berkompetisi.

Bekal kemampuan menggunakan dan memanfaatkan perangkat teknologi informasi dan komunikasi merupakan salah satu faktor kunci untuk mengejar ketertinggalan Sumber Daya Manusia (SDM) Indonesia dari bangsa-bangsa lain. Program-program pendidikan dan latihan secara formal maupun non formal yang memberikan bekal ketrampilan dan kemampuan dalam menggunakan dan memanfaatkan perangkat teknologi informasi dan komunikasi menjadi prioritas kebutuhan. Jalur pendidikan formal berpotensi dan bernilai strategis untuk menyelenggarakan pendidikan dan latihan di bidang TIK yang idealnya dimulai sejak dini. Hal ini mengisyaratkan pentingnya bagi semua orang sejak dini disediakan pengalaman dalam memanfaatkan sarana teknologi informasi dan komunikasi khususnya komputer yang bermanfaat sebagai bekal kemampuan dasar dan potensi untuk belajar sepanjang hayat dan memecahkan masalah yang akan dihadapi 
dalam kehidupannya kelak.( Ifan Wiranto, 2015)

Banyaknya kegiatan yang ada di desa khususnya dalam hal administrasi dan keuangan di desa yang berhubungan dengan pembangunan infratruktur dan pembagian bantuan sosial serta program-program yang yang dikeluarkan oleh pemerintah untuk kepentingan desa seperti bedah rumah, raskin, jamkesmas, sertifikat gratis dan lainlain serta pengembang produk unggulan desa. Tentu semua ini membutuhkan pendataan dan data yang lengkap di desa agar bantuan tepat sasaran.

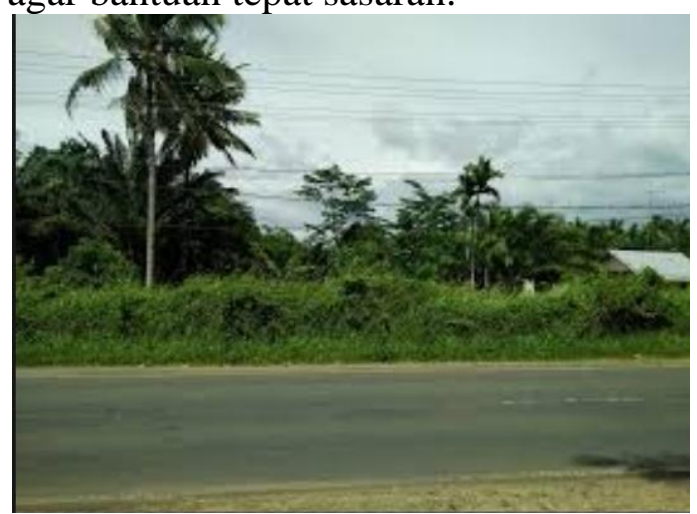

Gambar 1.5. Kondisi Wilayah

Hambatan yang dialami oleh aparat desa untuk pencairan dana bantuan atau pengalokasian terkendala dengan data yang ada dikarena masih sederhana dan pendataannya masih secara sederhana sehingga membutukan waktu yang lama untuk menyusun proposal yang diajukan dan kadang karena keterbatasan kemampuan aparat desa yang berhubungan dengan teknologi khususnya komputer menghambat mereka dalam bekerja dan minimnya kemampuan menyusun proposal dan data keuangan sehingga bantuan yang diberikan dapat segera cairkan oleh pemerintah. Dengan pelatihan dikembangkannya maka diharapakan dapat membantu para perangkat Desa Purbosari Kecamatan Seluma Barat Kabupaten Seluma, Digunakan pengolahan data elektronik, maka manfaat yang dapat diperoleh adalah meminimalkan kebutuhan tenaga manusia, hal ini karena beberapa pekerjaan dilakukan secara otomatis oleh peralatan bantuan seperti komputer. Keuntungan lain adalah kemampuan komputer untuk memproses data lebih besar, keakuratannya yang lebih besar, kecepatan yang lebih besar, fasilitas pengendalian otomatis dan pengolahan secara serentak. Komputer dapat digunakan untuk pembuatan faktur, pengolahan data pegawai, perhitungan pajak, surat menyurat dan lain-lain yang berhubungan dengan administrasi.

Berdasarkan permasalahan yang dikemukakan tersebut, maka tujuan dari pelatihan ini adalah memberi keterampilan dasar komputer dan teknologi internet kepada perangkat Desa Purbosari dalam aktifitas administrasi dapat menggunakan komputer sebagai alat bantu dalam memudahkan mereka dalam bekerja di balai desa. Karena sekarang ini hampir di semua sektor pekerjaan yang berhubungan dengan administrasi digunakan perangkat komputer yang selama ini dikerjakan dengan alat ketik konvensional yang tentu saja banyak kekurangan dan lambat dalam pengerjaannya dan juga diperkenalkan teknologi informasi untuk memudahkan memperoleh informasi-informasi yang penting yang bisa digunakan. Hampir semua kegiatan administrasi menggunakan komputer seperti office dan jaringan internet. Adapun manfaat yang dapat diambil dari kegiatan pengabdian masyarakat ini adalah :

a. Bagi perangkat desa dapat memperoleh pelatihan dasar dalam pengoperasian perangkat komputer, dasar-dasar aplikasi yang biasa digunakan dalam hal administrasi dan pengenalan internet dalam hal ini jaringan internet.

b. Bagi penyuluh bisa berbagi ilmu pengetahuan yang didapat sebagai implementasi dari tri darma perguruan tinggi, yang tidak hanya terpaku pada kalangan akademisi saja tetapi berguna juga dilingkungan sekitarnya.

c. Bagi perangkat Desa dengan pelatihan ini diharapkan perangkat desa lebih mahir dan bisa berkomunikasi dengan dunia luar dalam hal memperoleh informasi yang mereka butuhkan dalam 
sistem administrasi yang dilakukan sehari-harinya.

d. meminimalkan kebutuhan tenaga manusia, hal ini karena beberapa pekerjaan dilakukan secara otomatis oleh peralatan bantuan seperti komputer. Keuntungan lain adalah kemampuan komputer untuk memproses data lebih besar, keakuratannya yang lebih besar, kecepatan yang lebih besar, fasilitas pengendalian otomatis dan peengolahan secara serentak. Komputer dapat digunakan untuk pembuatan faktur, pengolahan data pegawai, perhitungan pajak, surat menyurat dan lain-lain yang berhubungan dengan administrasi.

e. Dengan pelatihan ini diharapkan perangkat desa bisa membuat proposal, surat menyurat, administrasi dan bisa mencari informasi secara langsung dengan menggunakan teknologi yang dipelajari.

\section{METODE KEGIATAN}

\subsection{Waktu dan Tempat Pelaksanaan}

Kegiatan Pelatihan Keterampilan Dasar Komputer dan Teknologi Informasi di laksanakan di Desa Purbosari Kecamatan Seluma Barat Kabupaten Seluma di lakukan selama 2 hari, dari tanggal 11-12 April 2017 di Kantor Balai Desa Purbosari Kecamatan Seluma Barat Kabupaten Seluma.

a. Persiapan :

1. Mengurus izin kepada kepala Desa Purbosari Kecamatan Seluma Barat Kabupaten Seluma.

2. Menentukan waktu pelaksanaan kegiatan pelatihan tentang pelatihan keterampilan dasar dan teknologi informasi bagi perangkat desa khususnya Desa Purbosari Kecamatan Seluma Barat Kabupaten Seluma.

3. Menghubungi atau menginformasikan kepada seluruh perangkat Keluarahaan untuk berkena hadir pada saat dan waktu yang telah ditentukan sesuai dengan undangan yang terlampir.

4. Mempersiapkan konsep kegiatan dan mempersiapkan prasarana yang dibutuhkan.

b. Pelaksanaan :

1. Setelah semua telah berkumpul, acara akan dimulai pada pukul 08.00 WIB dilakukan presentasi dengan media power point dengan perangkat LCD dengan dipancarkan ke dinding.

2. Membagi modul yang telah dibuat kepada para peserta dan telah diperbanyak sesuai jumlah peserta yang ada.

3. Diberikan materi dalam bentuk teori dan disajikan dalam bentuk presentasi didepan peserta.

4. Kemudian dilanjutkan dengan praktek secara langsung dengan perangkat komputer yang telah disediakan, juga dalam kesempatan ini kepada peserta diberikan kesempatn untuk Tanya jawab yang berhubungan dengan materi yang telah disampaikan.

5. Acara selesai pada pukul 16.00

\subsection{Pemecahan Masalah}

Untuk menyelesaikan permasalahan yang dihadapi mitra, solusi yang ditawarkan adalah melakukan pelatihan meningkatkan kemampuan aparat desa dalam menjalani microsoft office, Oleh karena itu, materi pelatihan meliputi lima hal berikut ini:

1. Pengenalan Dasar Komputer

2. Pengenalan Microsoft Word

3. Pengenal Mikrosoft Excel

4. Pembuatan Proposal dan pembukuan Praktis

5. Mengenal teknologi informasi

Desain materi pelatihan di atas diharapkan dapat meningkatkan beberapa kemampuan aparat desa , diantaranya sebagai berikut ini: 
1. Mempunyai kemampuan dasar dalam menjalankan komputer

2. Mampu membuat proposal dan suratsurat yang berhubungan dengan administrasi.

3. Mampu menyusun pembukuan sederhana

4. Mampu menggunakan media internet sebagai bagian dari teknologi informasi.

\subsection{Pelaksanaan}

Desa Purbosari memiliki Balai Desa tempat Pelaksanaan Kegiatan Pelatihan keterampilan dasar Komputer dan teknologi Informasi, Pelatihan Keterampilan Dasar Komputer yaitu bagaimana menggunakan program aplikasi Microsoft Office yaitu Word, Excel dan Internet . Peserta didik juga diajarkan bagaimana mereka bisa mengakses internet. Untuk peserta, setiap peserta harus didampingi untuk melatih mereka dalam menggunakan komputer.

Pelaksanaan kegiatan pengabdian ini dilaksanakan dalam ruang balai desa yang representative untuk kegiatan pelatihan ini, dalam menyampai materi, nara sumber menggunakan presentasi power point , pembagian modul dan metode tanya jawab. Bentuk kegiatan yang akan dilaksanakan adalah pelatihan keterampilan Dasar komputer dan Teknologi bagi perangkat desa, keterampilan yang akan diajarkan adalah Dasar Komputer, Microsoft Word, Microsoft Excel dan Pengenalan teknologi Informasi, aparat desa juga diajarkan mengakses internet untuk mencari informasi yang dibutuhkan. Bagi perangkat desa, pelatihan difokuskan pada pemanfaatan komputer untuk mengolah arsip, penyusunan proposal, pembukuan sederhana dan administrasi desa.

Tabel 1. Uraian Pekerjaan, Program dan Volumenya dalam 2 Hari

\begin{tabular}{|c|l|l|l|} 
& Microsoft Word & & \\
\hline 3 & $\begin{array}{l}\text { Pelatihan membuat } \\
\text { proposal }\end{array}$ & $\begin{array}{l}\text { Trampil dengan } \\
\text { Microsoft } \\
\text { Word }\end{array}$ & 5 Jam \\
\hline 4 & $\begin{array}{l}\text { Pelatihan pengolahan } \\
\text { data keuangan } \\
\text { menggunakan } \\
\text { Microsoft Excel }\end{array}$ & $\begin{array}{l}\text { Trampil dengan } \\
\text { Microsoft Excel } \\
\text { kalam menyusun } \\
\text { keuangan }\end{array}$ & 6 Jam \\
\hline 5 & $\begin{array}{l}\text { Pelatihan mengakses } \\
\text { Internet }\end{array}$ & Akses Internet & 5 Jam \\
\hline
\end{tabular}

\section{HASIL DAN PEMBAHASAN}

\section{A. Hasil}

Kegiatan pengabdian masyarakat ini diikuti oleh perangkat kelurahaan di Desa Purbosari Kecamatan Seluma Barat Kabupaten Seluma.setelah terlebih dahulu pemberitahuan kepada perangkat kelurahaan setempat, diharapkankan dengan pelatihan ini bisa berguna dan bermanfaat bagi perangkat kelurahaan dan perkembangan kedepan.

Pelaksanaan Pengabdian ini dilaksanakan selama 2 Hari terhitung mulai tanggal 11-12 April 2017 di Kantor Balai Desa Purbosari Kecamatan Seluma Barat Kabupaten Seluma. Tahapan pencapaian target hasil diuraikan menurut runtutan metode pelaksanaan dengan beberapa modifikasi sesuai kondisi lapangan, dan selanjutnya secara detail diuraikan berikut :

\subsection{Pembekalan/pematangan Rencana}

Pembekalan peserta ditujukan untuk memberikan pemahaman dasar atas tema yang diusung, pelatihan penggunaan modul, akomudasi, konsumsi, peralatan yang dibutuhkan dalam pelatihan dan hal-hal yang lain yang dibutuhkan.

\begin{tabular}{|c|l|l|l|}
\hline No & Nama Pekerjaan & \multicolumn{1}{|c|}{ Program } & $\begin{array}{c}\text { Volume } \\
\text { (JKEM) }\end{array}$ \\
\hline 1 & $\begin{array}{l}\text { Pengenalan sistem dan } \\
\text { cara kerja komputer }\end{array}$ & $\begin{array}{l}\text { Pengenalan } \\
\text { Komputer }\end{array}$ & 4 Jam \\
\hline 2 & $\begin{array}{l}\text { Pelatihan pengolahan } \\
\text { data menggunakan }\end{array}$ & $\begin{array}{l}\text { Trampil dengan } \\
\text { Microsoft Word }\end{array}$ & 4 Jam \\
\hline
\end{tabular}




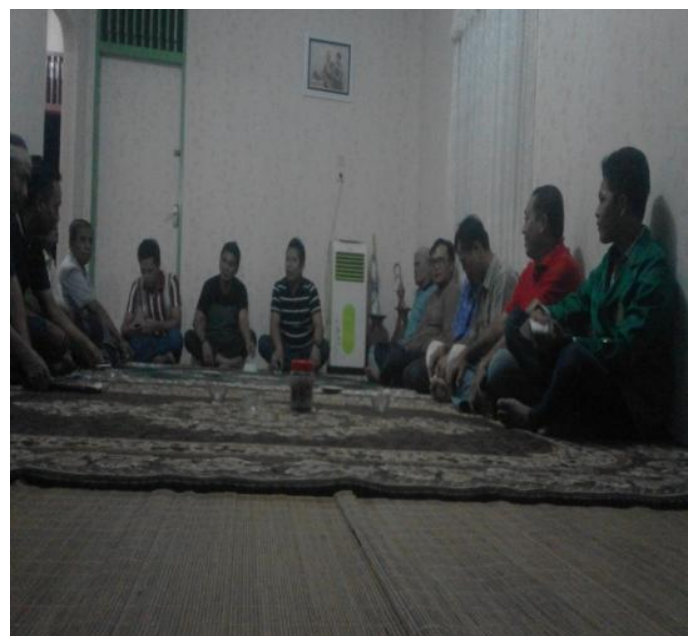

Gambar. 3.1. Pematang persiapan PKM

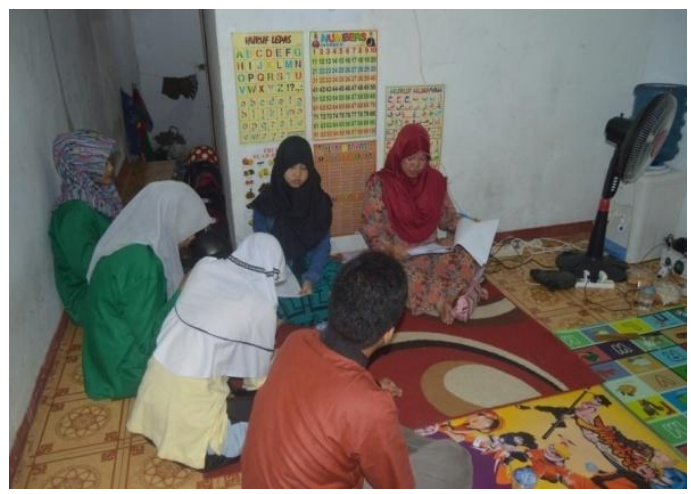

Gambar. 3.2 Diskusi sebelum Pelaksanaan

\subsection{Pelaksanaan Program}

Tahapan Pelaksanaan Program dengan melaksanakan pelatihan dasar komputer dan Teknologi Informasi.

a. Pengenalan sistem dan cara kerja komputer.

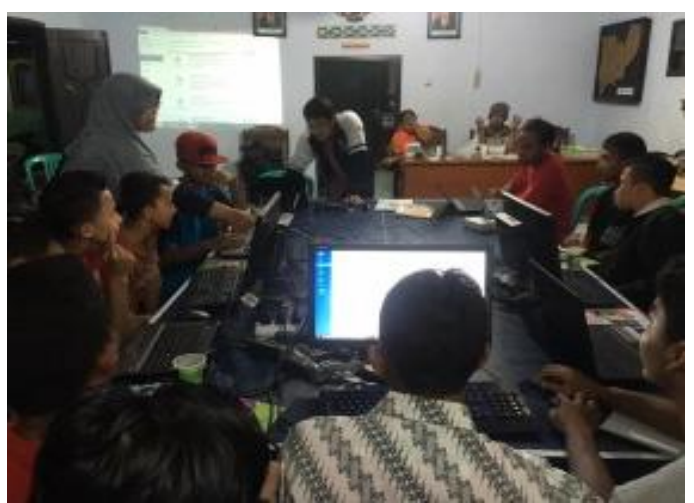

Gambar 3.3. Penegenalan Dasar Komputer b. Pelatihan pengolahan data dengan Microsoft Word

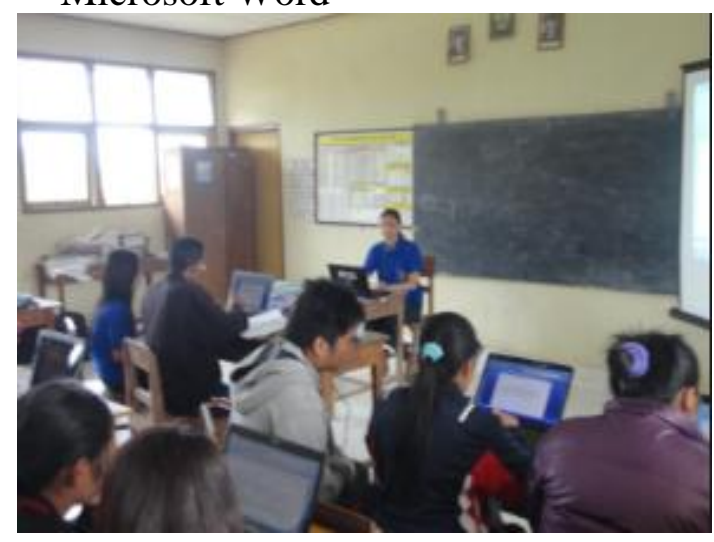

Gambar 3.4. Pengolahan Data

c. Pelatihan membuat proposal

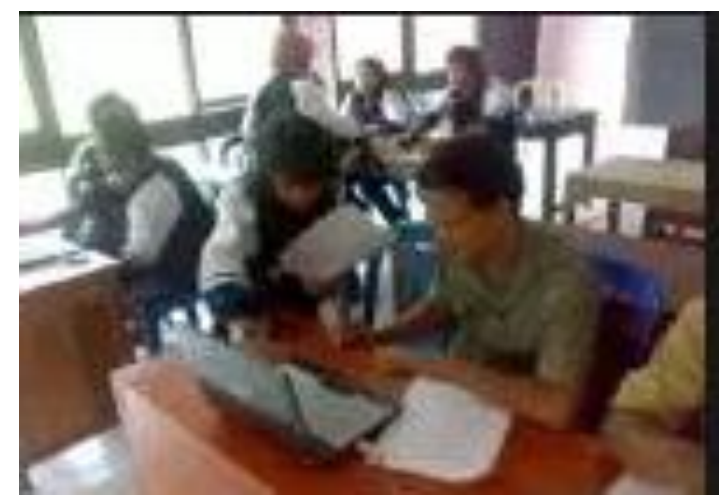

Gambar 3.5. Pelatihan Pembuatan Proposal

d. Pelatihan pengolahan data keuangan dengan Microsoft Excel

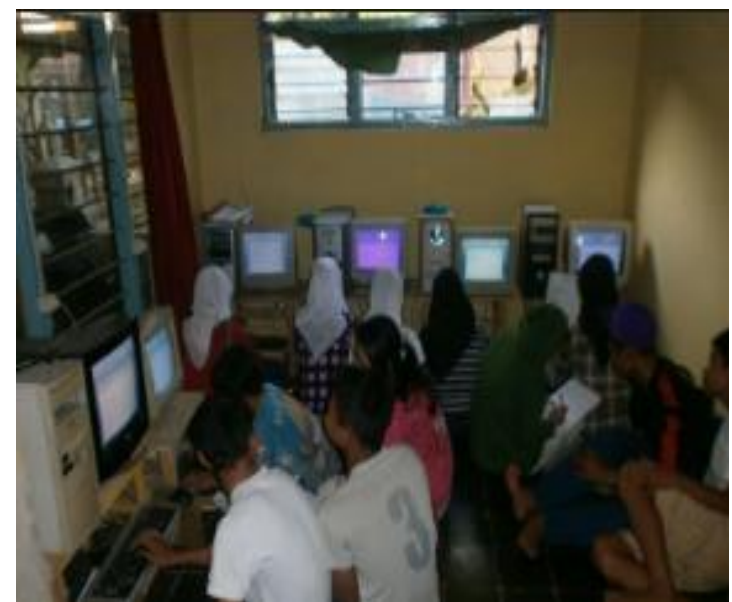

Gambar 3.6. Pengolahan data keuangan dengan Microsoft Excel 


\section{e. Pelatihan Mengakses Internet}

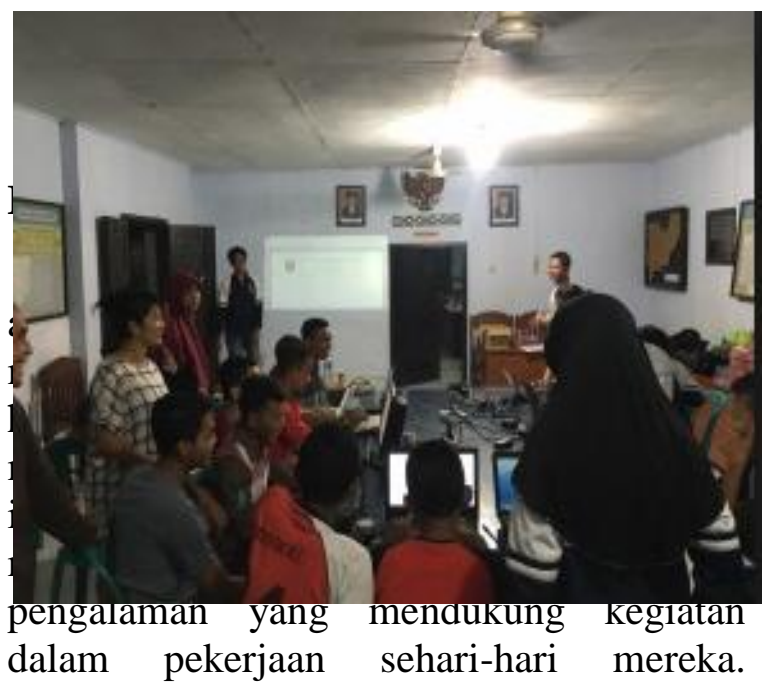

Kegiatan atas bentuk pelatihan pada perangkat desa, setelah rangkaian kegiatan telah dilaksanakan dengan dengan mencapai hampir $85 \%$ sesuai dengan laporan bukti kegiatan telah dilakukan. Kegiatan Pelatihan Keterampilan Dasar Komputer Dan Teknologi Informasi Bagi Perangkat Desa Purbosari Kecamatan Seluma Barat Kabupaten Seluma ini sebagian telah dilaksanakan, yaitu tahap koordinasi dan survey, sosialisasi kegiatan dan pelatihan. Untuk kedepannya tahapan kegiatan yang belum dilaksanakan yaitu untuk tahap pendampingan sehingga lebih optimal. Dari kegiatan yang telah dilaksanakan, mendapatkan bantuan baik pengetahuan, moril dan materiil. Luaran yang diharapkan adalah :

1. Perangkat desa mampu menggunakan komputer untuk mengaplikasikan program Word, Excel, dan Pembukuan sederhana serta mampu mengakses internet

2. Perangkat desa memiliki kemampuan untuk memanfaatkan komputer untuk mengolah arsip dan administrasi desa.

3. Perangkat desa mampu membuat pembukuan sederhana

4. Perangkat desa mampu menggunakan teknologi informasi dengan internet untuk melihat kemajuan daerah untuk di terapkan di daerahnya sendiri.

Hambatan yang di temukan beberapa praktik yang dilaksanakan kurang produktif, hal ini dikarenakan kondisi perangkat komputer maupun jumlah prasarana yang belum memadahi sehingga menghambat kegiatan pelatihan praktik sehingga memerlukan waktu yang lebih lama untuk melaksanakan pelatihan dan koneksi internet yang tidak stabil karena jauh lokasi dari menara provaider serta minimnya kemampuan aparat karena ratarata kurang ke ilmuan tentang aplikasi yang ada di dalam komputer yang bisa membantu pekerjaan dalam hal administrasi, pembukuan dan surat menyurat.

\section{PENUTUP \\ Kesimpulan}

Dari rangkaian proses kegiatan

Pengabdian Desa Purbosari Kecamatan Seluma Barat Kabupaten Seluma.yang telah dilakukan, menghasilkan :

a. Ilmu pengetahuan dan teknologi adalah suatu bagian yang tidak dapat dilepaskan dari kehidupan manusia dari awal sampai diakhir peradaban, kemajuan dibidang teknologi disertai dengan pemikiran-pemikiran manusia yang semakin berkembang, perkembangan teknologi memang sangat diperlukan setiap inovasi diciptakan untuk member dampak yang positif bagi kehidupan manusia itu sendiri, memberikan banyak kemudahan, serta sebagai cara baru dalam melakukan aktifitas manusia.

b. Dengan digunakan pengolahan data elektronik, maka manfaat yang dapat diperoleh adalah meminimalkan kebutuhan tenaga manusia, hal ini karena beberapa pekerjaan dilakukan secara otomatis oleh peralatan bantuan seperti komputer. Keuntungan lain adalah kemampuan komputer untuk memproses data lebih besar, keakuratannya yang lebih besar, kecepatan yang lebih besar, fasilitas pengendalian otomatis dan peengolahan secara serentak. Komputer dapat digunakan untuk pembuatan faktur, pengolahan data pegawai, perhitungan 
pajak, surat menyurat dan lain-lain yang berhubungan dengan administrasi.

c. Dengan pelatihan ini diharapkan perangkat desa bisa membuat proposal, surat menyurat, pembukuan sederhana, administrasi dan bisa mencari informasi secara langsung dengan menggunakan teknologi yang dipelajari.

\section{Saran}

Diharapkan dikemudian hari masyarakat dimanapun mereka berada dapat tersentu oleh teknologi dan dapat dengan mudah memperoleh akses informasi walaupun mereka di daerah yang terpencil demi pemerataan pembangunan dan mereka bisa memperoleh ilmu pengetahuan yang bisa meningkatkan hasil pekerjaan juga info perkembangan di luar.

\section{DAFTAR PUSTAKA}

1. Ifan Wiranto,ST.MT, Bambang Panji Asmara,ST., MT, Ade Irawaty Tolago, ST.,MT. 2015. Pelatihan keterampilan Dasar Komputer Dan Teknologi Informasi Bagi Siswa Sekolah Dasar Dan Perangkat Desa Alata Karya Kecamatan Kwandang Kabupaten Gorontalo Utara, KKS Pengabdian Lembaga Pengabdian Masyarakat Universitas Negeri Gorontalo.

2. Sriyoto, Bambang Sumantri. 2016. Kajian Peningkatan Pendapatan Pengrajin Gulakelapa Di Desa Purbosari Kecamatan Seluma Barat Kabupaten Seluma, Jurnal AGRISEP, 16(1)
3. Eva Ardiana Indrariani, S.S., M.Hum, Icuk Prayogi, S.S., M.A, Ririn Ambarini, S.Pd., M.Hum Nugroho Dwi Saputro, S.Kom., M.Kom, Rahmat Robi Waliansyah, S.Kom., M.Kom. 2018. Pkm Bagi Para Ibu Anak Usia Dini Di Desa Welahan Jepara, Laporan Program Kemitraan Masyarakat (PKM), Lembaga Penelitian dan Pengabdian Kepada Masyarakat Universitas PGRI Semarang.

4. Tona Aurora Lubis, Junaidi. 2016. Pemanfaatan Teknologi Informasi Pada Usaha Mikro Kecil Dan Menengah Di Kota Jambi, Jurnal Perspektif Pembiayaan dan Pembangunan Daerah Vol. 3 No. 3

5. I Dewa Made Adi Baskara Joni, I Putu Hendika Permana. 2017. Pengelolaan Kegiatan Pengabdian Masyarakat dengan Sistem Informasi Manajemen, LONTAR KOMPUTER, 8 (2)

6. Asroni, S.T., M.Eng, Haris Setyawan, S.T., M.Eng. 2016. Pelatihan MS Office dan Pembuatan Blog Di Dusun Kalitengah Lor, Glagaharjo, Cangkringan Sleman, Laporan Kegiatan Pengabdian Masyarakat, Fakultas Teknik, Universitas Muhammadiyah Yogyakarta

7. Sari Nainy Sapriesty, ST.,MT, Pramono Hadi Sholeh, Dr., Ir., MS, Kurniawan Fadila Dwi, ST., MT. 2015. PKM Pemanfaatan Teknologi Komunikasi Berbasis Internet Bagi Perangkat Desa Ladungsari, Laporan Pengabdian Kepada masyarakat, Fakultas Teknik Universitas Brawijaya. 